\title{
The Air Gap and Angle Optimization in the Axial Flux Permanent Magnet Motor
}

\author{
C. Akuner, E. Huner \\ Department of Electrical Education, Technical Education Faculty, Marmara University, \\ Goztepe Campus, 34734, Istanbul,Turkey,phone:+90 21633657 70/263, e-mails: akuner@marmara.edu.tr, \\ engin.huner@marmara.edu.tr
}

\section{Introduction}

Technological advances in recent years have led to the development of the axial flux permanent magnet motor. Its most important features are high torque at low speeds and high power density [1].

In this study, the axial flux permanent magnet motor and the length range of the air gap between rotors was analyzed and the appropriate length obtained.

$\mathrm{NdFeB}$ permanent magnets were used in this study. Permanent magnets can change the characteristics of the motor's torque. However, the distance between permanent magnets and the air gap will remain constant for each magnet.

$\mathrm{NdFeB}$ magnets were developed over the last twenty years. However, the axial flux motor is a new subject of research. Such research has focused on a new prototype motor. In the last decade, in particular, researchers have investigated the parameters of the axial flux motor.

Federico and his colleagues designed a multi part water cooled and coreless stator in 1996. In the designed motor, the reciprocal poles $\mathrm{N}$ and $\mathrm{S}$ was designed as a magnetic flux path through stator and rotor disk. Thus, the coreless stator reduced iron core losses.

Prufoma and his colleagues created the axial flux interior permanent magnet motor(AFIPM) from soft magnetic composite(SMC) in 1998. The AFIPM reduced magnetic reluctance. Additionally, interior magnets provided a strong structure for the rotor. By reducing the magnetic reluctance, of this new design allows to improve the motor flux weakening capability.

Parviainen and his colleagues have proposed the axial flux interior permanent magnet synchronous motor (AFIPM) in 2001. In their proposed design, the sinusoidal shape of the magnet reverses the electromotive forces to reduce the cogging torque. However, the disadvantages of this method are decreasing torque due to a decrease in the magnet volume [2].

Ernest A. Mendrela and Mariusz Jagiela proposed the use of the salient pole in the mono phase axial flux motor in 2004. This motor has an asymmetric magnet arrangement to produce a high torque. In this design, the motor is used as a water pump. It generates a high torque, requires little structure, is cost effective, and is available in an important field of application [3].

Locment and his colleagues, as part of a research project using SMC, developed the seven-phase axial flux motor in 2006. In order to reduce the cogging torque, various techniques have been proposed for 3-phase machines, such as shifting between the rotor discs. However, this simple technique is more interesting with a 7-phase machine.

Caricchi and his colleagues published a study, in 2002, of the magnets in the rotor rotating clockwise, and vice versa. They established a mechanism that is given in Fig. 1. They found that a skewing angle of about $19^{\circ}$ allows for a minimum cogging torque of about $7 \mathrm{~N}-\mathrm{m}$, about $80 \%$ less than the cogging torque measured with no skewing angle and less than $5 \%$ of the machine-rated torque.
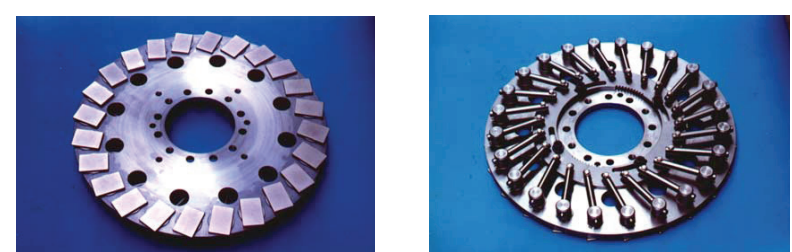

Fig. 1. Mechanism used for adjusting the magnet skewing

Aydın and his colleagues, in their study in 2007 study, proposed various skewing angles for magnets to reduce cogging torque. Skewing is very effective in minimizing cogging torque. The drawback is the additional complexity and manufacturing cost of such magnets. Hence, the combination of stator slot number and pole number affects the cogging torque significantly [4].

In the review of the literature, the prototype engine stands out. This study aims at improving the parameters of this engine.

With this study of axial magnetic flux in a range of 
motor types in general and the NN-type axial flux motor in particular optimum values have been obtained.

\section{The Geometry of the Developed Motor}

The design configuration of the axial flux permanent magnet motor is of the $\mathrm{NN}$ type. Magnets are affixed to the steel disc rotors and consists of two pieces.

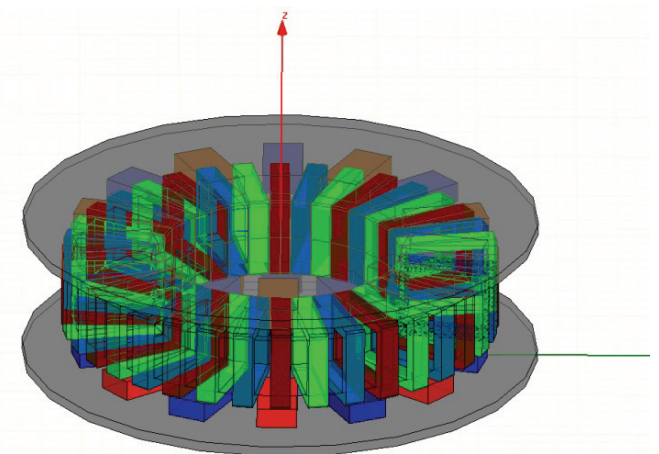

Fig. 2. NN-type permanent magnet axial flux motor

The rotor is made of a $0.5-\mathrm{mm}$ steel disc that is placed on the magnet. The magnet consists of 14 pieces. This magnets is of the N35 type of neodyum permanent magnets $(\mathrm{NdFeB})$.

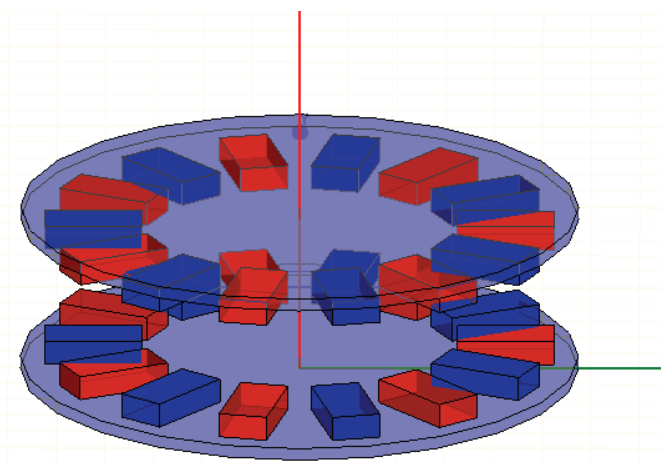

Fig. 3. Rotor structure of the NN-type axial flux motor

The stator is composed of packed $0.23 \mathrm{~mm}$ siliceous steel placed on 36 coil and 3-phase windings. The windings are as toroidal. An important feature of these windings is their short end connection. The magnetic flux path is given in Fig. 4.

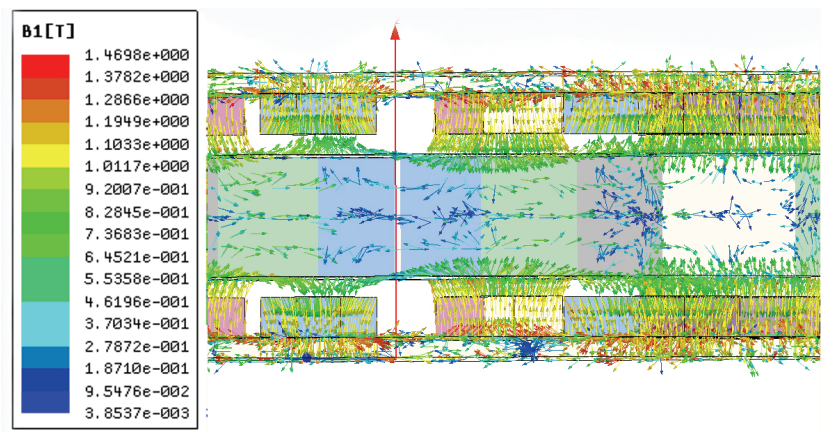

Fig. 4. Magnetic flux linkage of axial flux NN-type motor

The electrical parameters of the motor used in the study are given in Table 1 .
Table 1. Electrical and mechanical parameters of the axial flux motor

\begin{tabular}{|l|l|}
\hline Measures and properties of the permanent magnet \\
\hline Magnet: NdFeB & Remanance(Bc): 1.23 tesla \\
\hline Coercivity Hc: $890000 \mathrm{~A} / \mathrm{m}$ & $\begin{array}{l}\text { Maximum energy production } \\
(\mathrm{BH})_{\max }: 273.675\end{array}$ \\
\hline Thickness of the magnet :6.3mm \\
\hline Rotor measures & Internal diameter: $130 \mathrm{~mm}$ \\
\hline External diameter: $210 \mathrm{~mm}$ & Pole number: 14 \\
\hline Thickness: $5 \mathrm{~mm}$ & \\
\hline Stator features & Number of laps per bobbin: 27 \\
\hline $\begin{array}{l}\text { The length of the air gap: } \\
\text { 1mm }\end{array}$ & Coil number per phase:12 \\
\hline Coil type: toroidal & Resistance per phase:0.15ohm \\
\hline Wire diameter:1mm & Iron core thickness:30mm \\
\hline $\begin{array}{l}\text { Iron core outer diameter: } \\
210 \mathrm{~mm}\end{array}$ & \\
\hline Electrical features & Rated speed: $428 \mathrm{rpm}$ \\
\hline Rated current: $1.82 \mathrm{~A}$ & Maximum torque: $26 \mathrm{Nm}$ \\
\hline Rated output power: $1200 \mathrm{~W}$ &
\end{tabular}

\section{Theoretical Analysis}

In the axial flux motor, the electromagnetic torque of the motor is given as a function of radius. $b_{p}(r)$ is pole width, and $\tau(r)$ is the distance between two poles

$$
\tau(r)=\frac{2 \pi r}{2 p}=\frac{\pi r}{p}=\frac{\pi * 65}{7}=29,17 \mathrm{~mm} .
$$

In this design, the pole width $b_{p}(r)$ is taken as 20 $\mathrm{mm}$ :

$$
\begin{gathered}
b_{p}(r)=\alpha_{i} \tau(r)=\alpha_{i} \frac{\pi r}{p}, \\
\alpha_{i}=\frac{b_{p}(r)}{\tau(r)}=\frac{20}{29,17}=0,6856, \\
\alpha=\frac{B}{B} \Rightarrow B=\alpha \times B=0,8433 T .
\end{gathered}
$$

The analysis of FEM and the above calculations results in an average magnetic flux density (see Fig. 3) at the level of 0.8433 Tesla.

The line current density as a function of radius is calculated as in eq. 5

$$
A_{m}(r)=\frac{m_{1} \sqrt{2} N_{1} I_{a}}{p \tau(r)}=\frac{m_{1} \sqrt{2} N_{1} I_{a}}{\pi r} .
$$

The forces acting on the disc are calculated according to the law of Ampere's Law. This force creates the torque on the disc. This torque is calculated according to the eq. 8:

$$
\begin{gathered}
d \vec{F}_{x}=I_{a}\left(d \vec{r} \times \vec{B}_{g}\right)=A(r)\left(d \vec{S} \times \vec{B}_{g}\right), \\
I_{a} d \vec{r}=A(r) d \vec{S}=A_{m}(r) / \sqrt{2} d \vec{S},
\end{gathered}
$$$$
d T_{d}=r d F_{x}=r\left[k_{w 1} A(r) B_{a v g} d S\right]=2 \pi \alpha_{i} k_{w 1} A(r) B_{m g} r^{2} d r \cdot(8)
$$ 
The average electromagnetic torque generated by the axial flux permanent magnet motor(AFPM), according to (6) and (8), is as follows [4]

$$
d T_{d}=2 \alpha_{i} m_{1} I_{a} N_{1} k_{w 1} B_{m g} r d r .
$$

If the above eq. is integrated from Dout/2 to Din/2 with respect to $r$, the average electromagnetic torque may be written as follows

$$
\begin{gathered}
T_{d}=\frac{1}{4} \alpha_{i} m_{1} I_{a} N_{1} k_{w 1} B_{m g}\left(D^{2} \text { out }-D^{2}{ }_{\text {in }}\right)= \\
=\frac{1}{4} 0,6856 \times 3 \times 1.82 \times 324 \times 1 \times 1,23\left(210^{2}-130^{2}\right)= \\
=10.14 \mathrm{Nm} .
\end{gathered}
$$

\section{Magnetic examination of the axial flux motor through finite element analysis}

Based on the method of finite element analysis, the axial flux permanent magnet motor was analyzed using Maxwell 3D software. The main purpose of this analysis was to investigate the impact of the placement of the magnets in terms of distance and the angle.

Thus, the maximum magnetic flux density in the air gap can be achieved by positioning the magnets in a certain way. The increase of $\alpha_{i}$ as shown in Equation 8, will improve torque.

A magnetic analysis was performed using the following three steps.

$i$. Creating a three-dimensional model. As shown in Fig. 3, a three-dimensional model was created.

ii. Selection of the material. A three-dimensional element model was created for each material defined. The defined polarization direction was taken along the z-axis. Moreover, based on the analysis using the finite element method, the materials must be enclosed within a region defined in all models. The variable speeds defined by an air gap from $1 \mathrm{~mm}$ to $5 \mathrm{~mm}$ have different values. The angle between the magnets and the change in alpha were investigated.

Table 2. The technical parameters of the materials

\begin{tabular}{|l|l|}
\hline Stator lamination & MOH B-H curve \\
\hline Rotor_1 lamination & Steel_1008B-H curve \\
\hline Rotor_2 lamination & Steel_1008B-H curve \\
\hline Permanent magnet N & NdFeB35 B-H curve \\
\hline Permanent magnet S & NdFeB35 B-H curve \\
\hline Air gap & Air $(\mathrm{h}=1: 5 \mathrm{~mm})$ \\
\hline Section & vacuum \\
\hline The angle between the magnets & Alpha \\
\hline
\end{tabular}

iii. Analysis of the results. The solution type chosen was magneto static. The program automatically computed the meshes of the objects.

\section{Obtaining the simulation results}

Results of the analysis, presented in the following Figures, illustrated air gap flux density variations and the torque produced with different magnet angles.

Fig. 5 shows the torque produced on the copper wire.
The magnets were arranged with angles from $19^{\circ}$ up to $45^{\circ}$. As shown in Fig. 5, magnet angles of $21.2^{\circ}, 26^{\circ}, 31.4^{\circ}$, and $34.4^{\circ}$ produced the maximum torque.

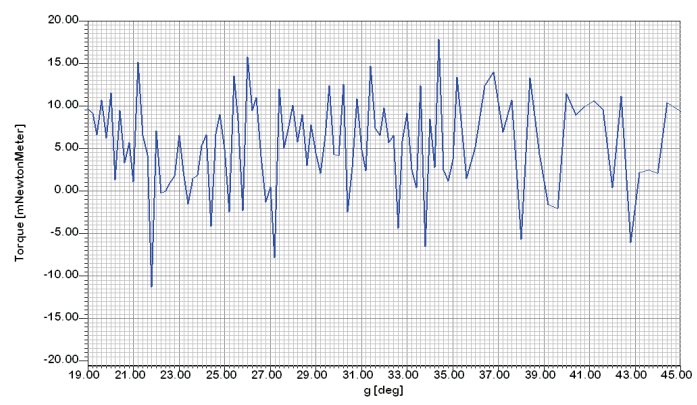

Fig. 5. Magnet angle - Torque variation

In Fig. 6, Fig. 7, Fig. 8, and Fig. 9, magnets were placed at angles of $21.2^{\circ}, 26^{\circ}, 31.4^{\circ}$, and $34.4^{\circ}$ respectively, depending on the contour in the middle of the magnet along the magnetic flux density.

Fig. 6 shows the results of using a magnet angle of $21.2^{\circ}$ and a magnet-to-air-gap distance from $19 \mathrm{~mm}$ to 15 mm. The magnetic flux difference, translated into flux density is 0.13 tesla.

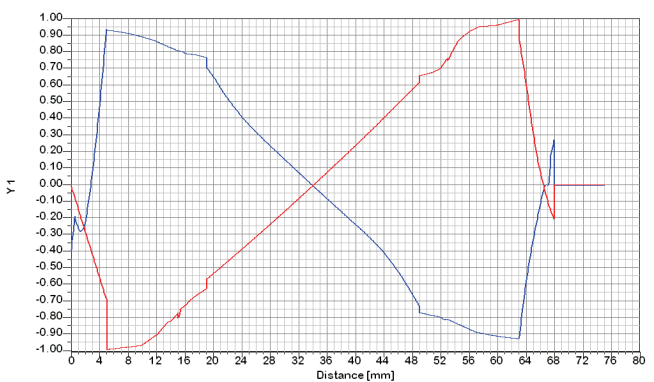

Fig. 6. The air gap flux density(magnet angle $=21.2^{\circ}$ )

Fig. 7 shows the result of using a magnet angle of $26^{\circ}$. In the air gap magnetic flux change is 0.01 Tesla.

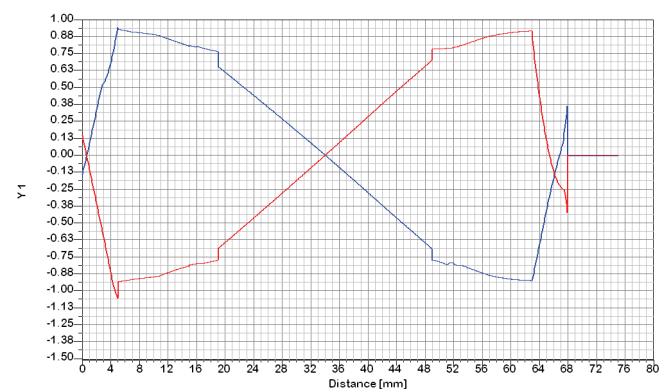

Fig. 7. The air gap flux density (magnet angle $=26^{\circ}$ )

Fig. 8 shows the result of using a magnet angle of $31.4^{\circ}$. In the air gap magnetic flux change is 0.16 Tesla..

Fig. 9 shows the result of using a magnet angle of $34.4^{\circ}$. In the air gap magnetic flux change is 0.48 Tesla.

The least flux exchange from Fig. 6, Fig. 7, Fig. 8, and Fig. 9 is $26^{\circ}$. With a magnet angle of $26^{\circ}$ and a magnet-to-air-gap distance of from 4_mm up to 19 mm, the axial flux permanent magnet motor is designed to operate at an optimum level. Flux density for two distance ranges is given in Fig.10 and Fig.11. These figures were created with the help of Maxwell software. 


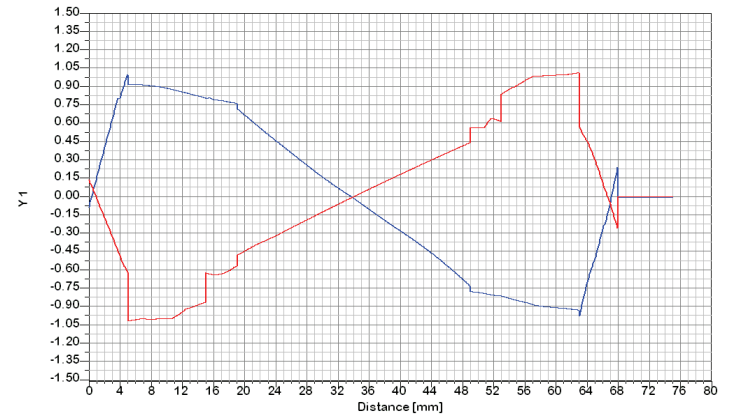

Fig. 8. The air gap flux density (magnet angle $=31.4^{\circ}$ )

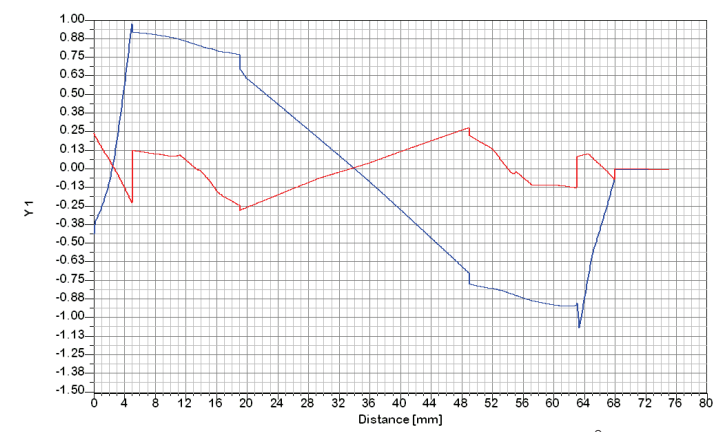

Fig. 9. The air gap flux density (magnet angle $=34.4^{\circ}$ )

\section{Conclusions}

The impact of different magnet angles for the axial flux permanent magnet motor and other motor parameters was examined. To this aim, the different angles and torque values of the magnetic flux density were calculated using the finite element method of analysis with the help of Maxwell 3D software. Maximum torque was obtained with magnet angles of $21^{\circ}, 26^{\circ}, 31.4^{\circ}$, and $34.4^{\circ}$.

Additionally, an important parameter for the axial flux permanent magnet motor in terms of the air gap flux was analyzed. Minimum flux change was obtained with a magnet angle of $26^{\circ}$.

In the Fig. 11, the magnetic flux of the magnet-to-airgap is under 0.5 tesla. Given the height of the coil, the magnet-to-air-gap distance most suitable for the axial flux permanent magnet motor was $4 \mathrm{~mm}$.

\section{Acknowledgements}

This work was supported by the commission on scientific research projects of Marmara University under Grant FEN-C-DRP-181208-0292.

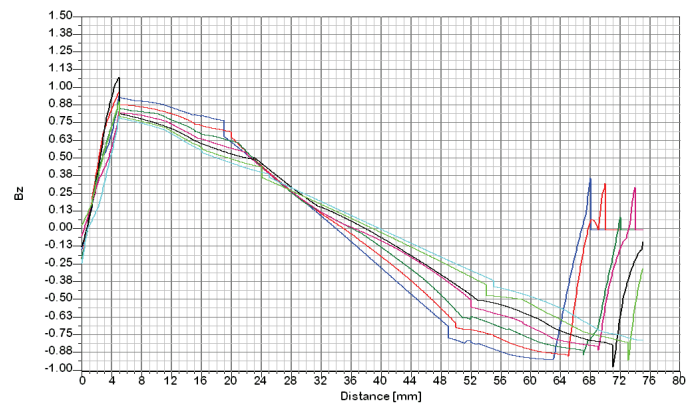

Fig. 10. Flux density contour (4_mm - 10_mm)

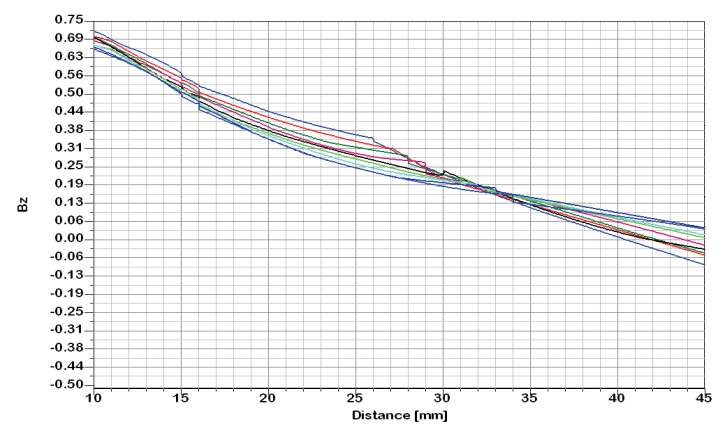

Fig. 11. Flux density contour (11_mm-19_mm)

\section{References}

1. Temiz I., Akuner C., Calik H. Analysis of Balanced ThreePhase Induction Motor Performance under Unbalanced Supply using Simulation and Experimental Results // Electronics and Electrical Engineering. - Kaunas: Technologija, 2011. - No. 3(109). - P. 41-45.

2. Parviainen A., Pyrhönen J., Niemela M. Axial Flux Interior Permanent Magnet Synchronous Motor with Sinusoidally Shaped Magnets // ISEF 10th International Symposium on Electromagnetic Fields İn Electrical Engineering. - Poland, Cracow, 2001. - P. 20-22.

3. Mendrela E. A., Jagiela M. Analysis of Torque Developed in Axial Flux, Single-Phase Brushless DC Motor With Salient-Pole Stator // IEEE Transaction On Energy Conversion, 2004. - Vol. 19. - No. 2.

4. Aydın M., Zhu Z.Q., Lipo T.A., Howe D. Minimization of Cogging Torque in Axial-Flux Permanent-Magnet Machines: Design Concepts // IEEE Transactions on Magnetics, 2007. - Vol. 43. - No. 9.

\section{Akuner, E. Huner. The Air Gap and Angle Optimization in the Axial Flux Permenant Magnet Motor // Electronics and}

Electrical Engineering. - Kaunas: Technologija, 2011. - No. 4(110). - P. $25-29$.

In this study, the axial flux permanent magnet motor and the length range of the air gap between rotors was analyzed and the appropriate length obtained. $\mathrm{NdFeB}$ permanent magnets were used in this study. Permanent magnets can change the characteristics of the motor's torque. However, the distance between permanent magnets and the air gap will remain constant for each magnet. The impact of different magnet angles for the axial flux permanent magnet motor and other motor parameters was examined. To this aim, the different angles and torque values of the magnetic flux density were calculated using the finite element method of analysis with the help of Maxwell 3D software. Maximum torque was obtained with magnet angles of $21^{\circ}, 26^{\circ}, 31.4^{\circ}$, and $34.4^{\circ}$. Additionally, an important parameter for the axial flux permanent magnet motor in terms of the air gap flux was analyzed. Minimum flux change was obtained with a magnet angle of $26^{\circ}$. The magnetic flux of the magnet-to-air-gap is under 0.5 tesla. Given the height of the coil, the magnet-to-airgap distance most suitable for the axial flux permanent magnet motor was 4 mm. Ill. 11, bibl. 4, tabl. 2 (in English; abstracts in English and Lithuanian). 
C. Akuner, E. Huner. Ašinio srauto variklių su nuolatiniu magnetu oro tarpo ir kampo optimizavimas // Elektronika ir elektrotechnika. - Kaunas: Technologija, 2011. - Nr. 4(110). - P. 25-29.

Analizuojama ašinio srauto variklių su nuolatiniu $\mathrm{NdFeB}$ magnetu oro tarpo įtaka rotoriams. Nuolatiniai magnetai gali tureti itakos variklio sukimo momento charakteristikoms. Atstumas tarp nuolatinių magnetų ir oro tarpas visada išliks pastovūs. Ištirti variklio parametrai ir magnetų padèties kampų įtaka ašinio srauto varikliams su nuolatiniais magnetais. Taikant baigtinių elementų metodą su programų paketu Maxwell 3D, ištirta skirtingu magnetų padèties kampų itaka sukimo momentui bei magnetinio srauto tankiui. Maksimalus sukimo momentas gautas esant $21^{\circ}, 26^{\circ}, 31,4^{\circ}$ ir $34,4^{\circ}$ kampams. Il. 11, bibl. 4, lent. 2 (anglų kalba; santraukos anglų ir lietuvių k.). 